\title{
Creation and study of raw material for grain sorghum breeding
}

\author{
$E A$ Vertikova $^{1, *}, V I$ Zhuzhukin $^{2}, V V$ Pylnev $^{1}$, and $L G$ Kurasova $^{2}$ \\ ${ }^{1}$ Moscow Agricultural Academy named after K.A. Timiryazev, Timiryazevskaya St., 49, 127550, \\ Moscow, Russia \\ ${ }^{2}$ Saratov State Agrarian University named after N.I. Vavilov, Teatralnaya Square, 1, 410012, Saratov, \\ Russia
}

\begin{abstract}
For the arid zone of the Lower Volga region, grain sorghum is an important forage crop. The paper presents the results of a comparative assessment of grain yield and biomass of breeding lines of grain sorghum in the nursery of preliminary variety testing. The volume of the nursery for the preliminary variety testing was 117 breeding lines. The most productive were the breeding lines of grain sorghum, the grain yield of which reached $3.95 \mathrm{t} /$ ha (line PSI-17 / EV-56); $4.10 \mathrm{t} /$ ha (line PSI-17 / EV-113); $4.15 \mathrm{t} /$ ha (line PSI-17 / EV-55); $4.50 \mathrm{t} /$ ha (line PSI-17 / EV92) with a yield of $3.75 \mathrm{t} /$ ha of the standard variety Volzhskoe 4 . As a result of scientific research, the promising breeding lines of grain sorghum were identified: PSI-17 / EV-56 and PSI-17 / EV-92, which were recommended to be submitted for competitive variety testing. It is advisable to use the breeding line of grain sorghum PSI-17 / EV-54V for early maturity. The breeding lines of grain sorghum: PSI-17 / EV-56 and PSI-17 / EV-90 are planned to be included in crosses to create varieties and hybrids with high grain quality. Breeding lines of grain sorghum: PSI-17 / EV-50, PSI-17 / EV-54, PSI-17 / EV-92 and PSI-17 / EV-127 are planned to be used in breeding for biomass yield.
\end{abstract}

\section{Introduction}

At the present stage, the economic development of agriculture in Russia requires a solution to the problem of the fodder industry. The development of this industry in the arid zone of Southeast Russia is strongly influenced by recurring droughts of various types. In the Volga region, a powerful reserve, in particular for the production of high-quality forage, are sorghum crops characterized by high drought resistance.

The main advantage of sorghum crops, first of all, is the variety of their use: grain fodder, silage, hay, haylage. It is necessary to note valuable biological qualities such as: increased foliage and bush, drought resistance, heat resistance. High productivity is particularly important. Sorghum crops form in dry years a higher yield than traditional crops, which is ensured by their exceptional qualities.

\footnotetext{
* Corresponding author: vertikovaea@yandex.ru
} 
Special attention in the Lower Volga region is paid to grain sorghum. Seed of grain sorghum contains $12-13 \%$ protein, $69-75 \%$ starch and $3.6 \%$ fat. One kilogram of grain sorghum is equivalent to 1.3 fodder units. Sorghum grains are processed into flour, cereal, starch. Grain sorghum is rich in proteins, carbohydrates, carotene, amino acids, mineral and tannins, vitamins E1, B1, B3 provitamin A. These substances are contained in the grain of sorghum more than in barley grain. In sorghum, the protein is not balanced in the composition of essential amino acids. Lysine and methionine have the greatest biological value. The amount of methionine in the sorghum protein varies from $1.23 \%$ to $1,98 \%$, and lysine from $1.82 \%$ to $2.48 \%$. The nutritional properties of the sorghum grain are almost equivalent to corn grain [1].

Agricultural producers grow sorghum mainly for fodder purposes. Poultry egg production increases by 26 to $31 \%$ if sorghum grain is added to the diet. Chickens grow rapidly and gain weight. When feeding pond fish (silver carp, crucian, carp) with sorghum grain, their live weight increases by $36 \%$ [1].

Sorghum is one of the oldest crops in the world of agriculture. Sorghum is native to Africa. Sorghum has been grown in India and China for more than three millennia to this day [1-3].

Sorghum was brought to the Volga region from the North Caucasus. Scientists from well-known Russian breeding centers started studying this crop and creating new varieties $[3]$.

In the world economy, the area of sorghum crops is increasing, due to the fact that they are increasingly used as animal feed. However, on the territory of the Russian Federation and the Volga region, as a result of the reform of agricultural production, the area of forage crops, including sorghum, has sharply decreased. Of course, the year 2020 can be considered unique, when the pandemic broke a positive trend in the development of agriculture in the region. Therefore, it is more important than ever for farmers to get higher profits at lower costs. At the same time, it should be noted that grain sorghum in the arid zones of the Lower Volga region is a universal crop. Among grain-forage crops, grain sorghum has no equal in drought resistance, while it is undemanding to soil fertility, can grow in saline areas, and provides stable yields in various crop rotations.

In order for grain sorghum to become widespread in the Volga region, it is necessary to provide agricultural producers with varieties and hybrids characterized by high drought resistance, early maturity, high productivity, resistance to diseases and pests, cold resistance, rapid starting growth, uniformity of ripening, the ability to mechanized harvesting [4-5].

The basis for the successful cultivation of crops in regions of the country with different natural and climatic conditions is the creation of varieties and hybrids adapted (adapted) to a specific area. In this regard, the variety has strict requirements: productivity, efficiency, environmentally safe quality [6].

The modern strategy of the breeding process presupposes an orientation towards real productivity; therefore, breeders have to take into account the variability of various economically useful traits in plants under conditions of varying environmental parameters [6-7].

For introducing sorghum crops into production, taking into account the diversity of soil and climatic conditions, one has to pay special attention to the different adaptability of the breeding material. In this regard, it is necessary in the test to study many varieties, variety samples and hybrids with both types of adaptability [8].

An important aspect in the grain sorghum breeding is the choice of methods for creating varieties and hybrids. Along with hybridization and selection of distinguished valuable genotypes, in sorghum crop breeding, the following are used: mutagenesis, polyploidy, somatic hybridization, transformation, heterosis breeding [9-12]. The breeding material 
obtained on the basis of various types of cytoplasm is characterized by a number of advantages and is actively used in breeding programs [12-16].

In order to increase the adaptability of the created varieties and hybrids of grain sorghum, it is necessary to use a well-established system of interaction with other breeding centers and production units of Russia and foreign countries. Exchange of data and breeding material makes it possible, first of all, to use the genetic diversity of the world collection and to conduct ecological tests of varieties and hybrids to establish their plasticity and productivity level. Close cooperation has been established between breeders of the Lower and Middle Volga regions, Krasnodar Territory, Kazakhstan, Moldova, Ukraine, Belarus and non-CIS foreign countries.

The creation of varieties and hybrids of grain sorghum is a complex and laborious process, which is aimed at acclimatizing this crop in the Volga region, increasing its productivity and early maturity [2].

In the Saratov region, breeders of such scientific institutions are engaged in the grain sorghum breeding: FSBSI RosNIISK "Rossorgo", FSBSI "Research Institute of Agriculture of Southeast", FSBEI HE "Saratov SAU". Dozens of varieties and hybrids of sorghum crops of various uses with high productivity and quality of grain and biomass adapted to the arid regions of the Russian Federation have been created and included in the State Register of Breeding Achievements [17-18].

The purpose of these scientific research was to study the source material for the grain sorghum breeding. To achieve this goal, the following tasks were solved: assessment of breeding material for grain sorghum in the nursery for preliminary variety testing; identification of promising breeding lines based on a complex of economically valuable traits; transfer for study in competitive variety testing.

\section{Material and research methods}

In the nursery of preliminary variety test, constant breeding lines of grain sorghum were studied, obtained as a result of intervariety and interspecific crosses at the Department of Plant Production, Breeding and Genetics of the Saratov State Agrarian University under the guidance of the Candidate of Agricultural sciences E.V. Morozov and transferred from the control nursery. The volume of the preliminary variety testing nursery was 117 breeding lines, which were distinguished by a complex of characters in 2016, after studying in the control nursery. The best regionized varieties of grain-fodder sorghum were used as standards: early-ripening variety Perspective 1 and later-ripening variety Volzhskoe 4.

Field and laboratory experiments were carried out according to the method of B.A. Dospekhova [19]. Experimental plots in the nursery for preliminary variety tests with a counting area of $5.0 \mathrm{~m} 2$ were placed in a randomized manner, in three and four replicates. Control over the development and growth, duration of phenological phases, breeding assessment of economically valuable traits was carried out in accordance with the methodology of the "Wide unified CMEA classifier and the CMEA international classifier of cultivated species of the genus Sorghum Moensh" [20]. The stages of organogenesis were assessed by the method of F.M. Kumerman [21].

Field experiments on the study of breeding material were carried out in the fields of the Povolzhye educational research and production association in the Engels district of the Saratov region. Chemical analysis was carried out in the laboratory using previously collected samples.

The data obtained were processed by the method of dispersion analysis with multiple comparisons of quotient means according to Duncan's test using the programs of statistical and biometrical-genetic analysis in crop production and breeding "Agros" version 2.09 [4]. 
On average, agrometeorological conditions of 2017 to 2019 can be estimated as typical for the zone of the Saratov Left Bank, which made it possible to comprehensively evaluate and characterize the breeding lines of grain sorghum in the nursery for preliminary variety testing by a set of traits and properties.

\section{Results and discussion}

Evaluation of the color of seedlings and the duration of the period of "sowing-seedlings" in the breeding lines of grain sorghum in the nursery of preliminary variety testing showed a significant variability in color. Many breeding lines were bright anthocyanin coloration, others were green.

Plant height after 30 days in the Volga region characterizes the cold resistance of the samples. In the variety-standard Perspective 1, this indicator is statistically significantly higher than that of the standard Volzhskoe 4. The breeding lines PSI-17 / EV-50, PSI-17 / EV-29, PSI-17 / EV-56, PSI- 17 / EV-98, PSI-17 / EV-121 were significantly inferior to the early maturing standard by an average of $15.7 \%$. It should be noted the line PSI-17 / EV-98, which had a reliably low plant height after 30 days, but in terms of plant height during ripening, it statistically significantly exceeded the Perspective 1 variety by an average of 4.3\% (table 1). 
Table 1. Assessment of varieties and best breeding lines of grain sorghum by economically valuable traits and biometric indicators, 2017 to 2019.

\begin{tabular}{|c|c|c|c|c|c|c|c|}
\hline \multirow[b]{2}{*}{$\begin{array}{c}\text { Variety, } \\
\text { breeding line }\end{array}$} & \multicolumn{2}{|c|}{ Plant height, $\mathrm{cm}$} & \multicolumn{2}{|c|}{ Leaf, $\mathrm{cm}$} & \multicolumn{2}{|c|}{ Panicle, $\mathrm{cm}$} & \multirow{2}{*}{$\begin{array}{c}\text { Panicle } \\
\text { leg } \\
\text { extension, } \\
\mathrm{cm}\end{array}$} \\
\hline & $\begin{array}{l}30 \text { days } \\
\text { after } \\
\text { seedlings }\end{array}$ & $\begin{array}{c}\text { At } \\
\text { maturation }\end{array}$ & 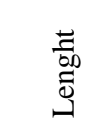 & 吾 & $\begin{array}{l}\overrightarrow{7} \\
\frac{0}{60} \\
\overline{0} \\
-1\end{array}$ & $\frac{5}{5}$ & \\
\hline $\begin{array}{c}\text { Perspective } \\
1(\mathrm{st})\end{array}$ & 48 & 94 & 34.7 & 4.1 & 13.6 & 3.9 & 19.2 \\
\hline $\begin{array}{c}\text { Volzhskoe } 4 \\
\text { (th) }\end{array}$ & 43 & 105 & 50.0 & 5.5 & 24.0 & 5.5 & 3.5 \\
\hline PSI-17/EV 29 & 46 & 138 & 46.5 & 6.5 & 26.0 & 3.8 & 16.0 \\
\hline PSI-17/EV-42 & 58 & 125 & 44.0 & 5.2 & 20.5 & 4.5 & 26.0 \\
\hline PSI-17/EV-44 & 49 & 120 & 48.0 & 6.2 & 21.5 & 5.0 & 13.0 \\
\hline PSI-17/EV-47 & 53 & 110 & 33.0 & 5.2 & 19.0 & 3.5 & 14.0 \\
\hline PSI-17/EV-50 & 40 & 105 & 57.0 & 5.8 & 20.0 & 3.5 & 17.0 \\
\hline PSI-17/EV-54 & 62 & 87 & 56.0 & 6.5 & 24.0 & 3.5 & 3.0 \\
\hline PSI-17/EV-55 & 68 & 115 & 42.0 & 4.5 & 23.5 & 3.5 & 18.0 \\
\hline PSI-17/EV-56 & 45 & 110 & 48.0 & 6.5 & 21.2 & 4.5 & 7.0 \\
\hline PSI-17/EV-64 & 58 & 108 & 40.0 & 5.2 & 17.0 & 3.5 & 17.0 \\
\hline PSI-17/EV-74 & 56 & 115 & 30.0 & 8.5 & 35.0 & 5.3 & 15.0 \\
\hline PSI-17/EV-78 & 68 & 115 & 35.5 & 3.8 & 20.5 & 7.5 & 27.0 \\
\hline PSI-17/EV-80 & 57 & 115 & 32.0 & 3.8 & 16.5 & 4.5 & 22.0 \\
\hline PSI-17/EV-85 & 78 & 128 & 37.0 & 4.2 & 23.5 & 4.2 & 16.0 \\
\hline PSI-17/EV-90 & 78 & 132 & 40.5 & 5.0 & 24.0 & 4.5 & 14.5 \\
\hline PSI-17/EV-92 & 72 & 142 & 53.5 & 5.8 & 26.0 & 5.2 & 8.0 \\
\hline PSI-17/EV-98 & 40 & 98 & 41.0 & 4.8 & 24.5 & 5.2 & 13.5 \\
\hline PSI-17/EV-100 & 72 & 138 & 48.0 & 4.4 & 16.5 & 5.0 & 16.5 \\
\hline PSI-17/EV-109 & 62 & 115 & 42.0 & 5.2 & 23.0 & 9.0 & 14.5 \\
\hline PSI-17/EV-113 & 57 & 120 & 47.0 & 4.2 & 23.0 & 10.3 & 11.0 \\
\hline PSI-17/EV-117 & 48 & 117 & 46.0 & 5.5 & 25.0 & 4.2 & 11.5 \\
\hline PSI-17/EV-120 & 50 & 128 & 47.0 & 5.5 & 26.5 & 4.5 & 19.0 \\
\hline PSI-17/EV-121 & 35 & 78 & 47.0 & 3.5 & 20.5 & 4.0 & 7.0 \\
\hline PSI-17/EV-124 & 50 & 105 & 44.0 & 3.8 & 20.5 & 4.5 & 13.0 \\
\hline PSI-17/EV-127 & 52 & 105 & 55.0 & 5.5 & 29.0 & 6.2 & 8.0 \\
\hline PSI-17/EV-129 & 55 & 100 & 44.0 & 5.5 & 25.5 & 4.5 & 4.0 \\
\hline$F_{\text {fact }}$ & $10.480^{*}$ & 4. $197 *$ & $8.480 *$ & $5.015^{*}$ & 10. $480 *$ & 9. $534^{*}$ & $15.298^{*}$ \\
\hline $\mathrm{LSD}_{05}$ & 1.35 & 2.35 & 1.25 & 0.9 & 1.40 & 1.10 & 2.50 \\
\hline
\end{tabular}

$* \mathrm{~F}_{\text {fact. }} \geq \mathrm{F}_{\text {calc }}$ (hereinafter)

As a result of three-year observations, it was established that the climatic conditions of the sorghum vegetation, starting from the last ten days of June until harvesting with a persistent and prolonged air and soil drought, cause a decrease in plant height during ripening, especially in the group of mid-ripening breeding lines.

The selection line PSI-17 / EV-54, on the contrary, showed an active initial growth, but at maturation, the plant height was characterized by a significantly lower value than that of the Perspective 1 variety on average by $7.45 \%$, which indicates the ultra-early maturity of this line. 
The regionized standard variety Volzhskoe 4 had a height of $105 \mathrm{~cm}$ for harvesting, which is significantly higher than that of the early ripening variety on average by $11.7 \%$ (94 $\mathrm{cm})$. The tallest, on average, for three years among the studied lines, was the PSI-17 / EV92 breeding line, which had a trait value significantly higher than that of the standard varieties by an average of $43.1 \%$. The PSI-17 / EV-121 line had a significantly lower ripening height on average by $16.35 \%$ (table 1). Most of the breeding lines of grain sorghum in the nursery of preliminary variety tests showed high plasticity and adaptability to arid growing conditions, formed herbage when ripe with a height of $100 \mathrm{~cm}$ or more (table 1).

In the nursery of preliminary variety tests of grain sorghum, a wide variety of breeding lines was revealed by morphological characteristics: number of leaves, length and width of largest leaf, flag leaf, size and shape of panicle, panicle leg extension and length of the panicle internode, thickness and nature of the main stem core.

The leaf length of the late-ripening variety Volzhskoe 4 was noted at a level of $50.0 \mathrm{~cm}$, which is $44.1 \%$ lower than that of the early-maturing variety Perspective 1 . Breeding lines PSI-17 / EV-47, PSI-17 / EV-74 and PSI- 17 / EV-80 had the value of the studied trait significantly lower than the early ripening variety, on average by $11.75 \%$. Breeding lines PSI-17 / EV-50, PSI-17 / EV-54, PSI-17 / EV-92 and PSI-17 / EV-127 statistically significantly exceeded the Volzhskoe standard variety (table 1) on average by $10.55 \%$.

The leaf width of the studied lines varied in the range from $3.5 \mathrm{~cm}$ to $8.5 \mathrm{~cm}$; panicle length - from $16.5 \mathrm{~cm}$ to $35.0 \mathrm{~cm}$; panicle width - from $3.5 \mathrm{~cm}$ to $10.3 \mathrm{~cm}$. On the basis of the combination of these features, the PSI-17 / EV-74 breeding line should be distinguished (table 1).

The extension of the panicle in the breeding lines ranged from $3.0 \mathrm{~cm}$ to $27.0 \mathrm{~cm}$. However, it should be noted that the most of the breeding lines of grain sorghum showed resistance to lodging and panicle fragility.

In accordance with the research program, there was carried out a comparative assessment of the productivity of breeding lines of grain sorghum at the end of the growing season (table 2). 
Table 2. Productivity, content of crude protein and starch in grain varieties and best breeding lines of grain sorghum, 2017 to 2019.

\begin{tabular}{|c|c|c|c|c|c|c|c|}
\hline \multirow{2}{*}{$\begin{array}{c}\text { Variety, } \\
\text { breeding line }\end{array}$} & \multicolumn{2}{|c|}{ Grain yield, $\mathrm{t}$ / ha } & \multicolumn{2}{|c|}{ Weight, g } & \multirow{2}{*}{$\begin{array}{c}\text { Dry } \\
\text { matter, \% }\end{array}$} & \multicolumn{2}{|c|}{$\begin{array}{c}\text { Content in dry } \\
\text { matter of grain, \% }\end{array}$} \\
\hline & biomass & grains & $\begin{array}{l}\text { grains } \\
\text { from one } \\
\text { panicle }\end{array}$ & $\begin{array}{l}1000 \\
\text { seeds }\end{array}$ & & Protein & Starch \\
\hline Perspective 1(st) & 8.5 & 1.72 & 7.0 & 31.4 & 89.75 & 13.09 & 67.43 \\
\hline Volzhskoe 4 (th) & 16.7 & 3.75 & 16.9 & 27.9 & 89.47 & 9.91 & 73.21 \\
\hline PSI-17/EV 29 & 18.2 & 2.65 & 13.9 & 28.2 & 89.12 & 15.27 & 67.53 \\
\hline PSI-17/EV-42 & 18.5 & 3.30 & 14.3 & 24.5 & 89.33 & 15.16 & 66.08 \\
\hline PSI-17/EV-44 & 17.0 & 2.40 & 16.0 & 18.5 & 89.45 & 17.53 & 63.63 \\
\hline PSI-17/EV-47 & 20.5 & 2.45 & 12.3 & 28.5 & 88.88 & 13.78 & 67.92 \\
\hline PSI-17/EV-50 & 20.0 & 2.60 & 10.0 & 18.4 & 90.00 & 12.69 & 67.20 \\
\hline $\begin{array}{l}\text { PSI-17/EV-54 } \\
\end{array}$ & 22.5 & 3.15 & 16.6 & 29.9 & 89.01 & 13.00 & 67.72 \\
\hline PSI-17/EV-55 & 23.0 & 4.15 & 23.1 & 30.3 & 90.99 & 14.63 & 60.30 \\
\hline PSI-17/EV-56 & 23.2 & 3.95 & 23.2 & 32.0 & 89.10 & 17.85 & 63.95 \\
\hline PSI-17/EV-64 & 17.5 & 3.35 & 14.0 & 25.2 & 88.96 & 14.50 & 63.42 \\
\hline PSI-17/EV-74 & 18.5 & 3.60 & 18.0 & 26.3 & 89.20 & 14.90 & 65.61 \\
\hline PSI-17/EV-78 & 20.5 & 3.92 & 22.9 & 29.0 & 89.23 & 13.89 & 67.93 \\
\hline PSI-17/EV-80 & 17.5 & 3.50 & 15.2 & 24.3 & 90.94 & 13.68 & 69.36 \\
\hline PSI-17/EV-85 & 15.5 & 2.35 & 15.7 & 26.0 & 90.35 & 15.06 & 68.70 \\
\hline PSI-17/EV-90 & 15.5 & 3.25 & 21.7 & 26.7 & 90.04 & 14.67 & 59.24 \\
\hline PSI-17/EV-92 & 26.3 & 4.50 & 21.4 & 28.8 & 89.65 & 13.03 & 69.65 \\
\hline PSI-17/EV-98 & 19.0 & 3.30 & 20.6 & 25.5 & 88.60 & 13.53 & 67.82 \\
\hline PSI-17/EV-100 & 18.5 & 3.55 & 20.9 & 21.7 & 89.13 & 14.64 & 61.77 \\
\hline PSI-17/EV-109 & 16.0 & 2.62 & 18.7 & 24.9 & 88.91 & 14.46 & 63.98 \\
\hline PSI-17/EV-113 & 19.0 & 4.10 & 25.6 & 28.7 & 89.46 & 11.45 & 69.67 \\
\hline PSI-17/EV-117 & 17.0 & 3.35 & 16.8 & 21.5 & 89.72 & 14.13 & 69.16 \\
\hline PSI-17/EV-120 & 20.5 & 2.34 & 15.6 & 21.7 & 88.85 & 11.26 & 67.72 \\
\hline PSI-17/EV-121 & 11.5 & 3.50 & 29.2 & 24.5 & 89.52 & 10.53 & 71.31 \\
\hline PSI-17/EV-124 & 17.0 & 3.10 & 14.8 & 22.8 & 89.19 & 11.51 & 70.05 \\
\hline PSI-17/EV-127 & 15.0 & 3.00 & 18.8 & 26.8 & 89.29 & 13.19 & 68.24 \\
\hline PSI-17/EV-129 & 14.0 & 3.50 & 21.9 & 25.8 & 88.95 & 13.47 & 67.37 \\
\hline$F_{\text {fact }}$ & $6.168^{*}$ & 4. 593* & $11.056^{*}$ & $9.014 *$ & - & - & - \\
\hline $\mathrm{LSD}_{05}$ & 2.45 & 0.32 & 2.80 & 3.60 & - & - & - \\
\hline
\end{tabular}

The most productive were the breeding lines of grain sorghum, the grain yield of which reached 3.95 t / ha (line PSI-17 / EV-56); 4.10 t / ha (line PSI-17 / EV-113); 4.15 t / ha (line PSI-17 / EV-55); $4.50 \mathrm{t} /$ ha (line PSI-17 / EV-92) with a yield of the standard variety Volzhskoe $4-3.75 \mathrm{t} /$ ha (table 2).

Medium-ripened breeding lines PSI-17 / EV-56 and PSI-17 / EV-92 were characterized by high biomass productivity. The statistically significant excess for the studied trait was on average $47.85 \%$.

In the nursery for preliminary variety testing of grain sorghum, the elements of productivity were assessed: the mass of grain from one panicle and the mass of 1000 seeds. The largest mass of seeds from one panicle ( $20 \mathrm{~g}$ and more) was found in 18 breeding lines. The selection line PSI-17 / EV-121 - $29.2 \mathrm{~g}$ (table 2) was characterized by the maximum value of the trait. Thin-stemmed, early-ripening breeding lines of grain sorghum, withstanding thickening of crops, formed panicles with a seed weight of $10 \mathrm{~g}$ or less.

Over the years of research, it has been established that arid growing conditions caused an acceleration in the passage of stages of organogenesis in grain sorghum, a reduction in 
interphase periods, and rapid formation and maturation of seeds. In some breeding lines of grain sorghum, this led to a decrease in the mass of 1000 grains and was reflected in the average value. The value of the trait varied in the breeding lines of grain sorghum in the range from $18.4 \mathrm{~g}$ to $31.4 \mathrm{~g}$. The largest seeds were the breeding lines PSI-17 / EV-55 (30.3 g) and PSI-17 / EV-56 (32, $0 \mathrm{~g})$.

The conducted biochemical evaluation of varieties and breeding lines of grain sorghum at nursery preliminary variety testing for the content of crude protein and starch revealed significant differences in the concentration of protein and starch in the grain (table 2).

Variation in the protein content in the grain of the breeding lines of grain sorghum was 10.53\% (line PSI-17 / EV-121) to $17.85 \%$ (line PSI-17 / EV-56). The starch concentration in the grain of the breeding lines of grain sorghum ranged from 59.24\% (line PSI-17 / EV55) to $71.31 \%$ (line PSI-17 / EV-90). Such a range of variability in the content of protein and starch in grain will allow the use of selected forms in further selection for quality.

\section{Conclusions}

- $\quad$ in the preliminary variety testing, according to a complex of characteristics and properties, promising breeding lines of grain sorghum were identified: PSI-17 / EB-56 and PSI-17 / EB-92, which were recommended to be submitted to competitive variety testing;

- $\quad$ in breeding for early maturity, it is advisable to use the PSI-17 / EB-54 breeding line of grain sorghum;

- PSI-17 / EV-56 and PSI-17 / EV-90 breeding lines of grain sorghum are planned to be included in crosses to create varieties and hybrids with high grain quality;

- PSI-17 / EV-50, PSI-17 / EV-54, PSI-17 / EV-92 and PSI-17 / EV-127 breeding lines for grain sorghum are planned to be used in breeding for biomass yield.

\section{References}

1. Vertikova E A 2018 Study of source material for selection of grain-fodder crops Agricultural scientific journal 3 (Saratov: OOO Amirit) 3-8 DOI: 10.28983 / asj.v0i3.399

2. Vertikova E A 2016 Selection of grain fodder crops in Volga region In world of scientific discoveries 9(81) (Krasnoyarsk) 74-93 DOI 10.12731/wsd-2016-9-74-93

3. Kibalnik O, Semin D, Gorbunov V et. al 2017 Directions of breeding of grain sorghum in the Lowel Volga region of Russia Agrobiodiversity for Improving Nutrition, Health and Life Quality $1226-229$

4. Shyurova N A, Subbotin A G, Zhuzhukin V I, Narushev V B, Ermolaeva G I and Bashinskaya O S 2019 Study of morphophysiological and economically valuable traits and properties of varieties of grain sorghum Agrarian Scientific Journal 12 (Saratov, OOO Amirit) 34-41 DOI: 10.28983/asj.y2019i12pp34-41

5. Elkonin L, Kibalnik O, Zavalishina A and Gerashchenkov $G 2018$ Genetic Function of Cytoplasm in Plants with Special Emphasis on Sorghum Chloroplasts and Cytoplasm. Structure and Function Sci. Publ. ed C Dejesus, L Trask (New York: Nova) pp 97-155

6. Kamthan A, Chaudhuri A, Kamthan M and Datta A 2016 Genetically modified (GM) crops: Milestones and new advances in crop improvement Theoretical and Applied 
Genetics 129 1639-55 DOI: 10.1007/s00122?016?2747?6

7. De Mesa-Stonestreet NJ, Alavi S, and Bean S R 2010 Sorghum proteins: the concentration, isolation, modification, and food applications of kafirins J. Food Sci. 75 90-104 DOI: 10.1111/j.1750?3841.2010.01623.x

8. Kumar T, Howe A, Sato S, Dweikat I and Clemente T 2012 Sorghum transformation: Overview and utility Plant Genetics and Genomics: Crops and Models 11 ed A H Paterson (New York, NY: Springer) 205-21 DOI: 10.1007/978?1?4419?5947?8_10

9. Wu E, Lenderts B, Glassman K, Berezowska-Kaniewska M, Christensen H, Asmus T, Zhen S, Chu U, Cho M J and Zhao ZY 2014 Optimized Agrobacterium mediated sorghum transformation protocol and molecular data of transgenic sorghum plants InVitro Cell. Dev. Biol.-Plant 50 9-18 DOI: 10.1007/s11627-013-9583-Z

10. Kumar T, Dweikat I, Sato S, Ge Z, Nersesian N, Elthon T, Bean S, Ioerger BP, Tiley $\mathrm{M}$ and Clemente T 2012 Modulation of kernel storage proteins in grain sorghum (Sorghum bicolor (L.) Moench) Plant Biotechnology Journal 10 533-44 DOI: 10.1111/j.1467-7652.2012.00685.x

11. Wong JH, Marx DB, Wilson JD, Buchanan BB, Lemaux PG and Pedersen JF 2010. Principal component analysis and biochemical characterization of protein and starch reveal primary targets for improving sorghum grain Plant Science 179 598-611 DOI: 10.1016/j.plantsci.2010.08.020

12. Belyaeva E V, Elkonin L.A. 2018 Expression of apomictic potentials and selection for apomixis in the progeny of sorghum (Sorghum bicolor (1.) Moench hybrid with male sterility The International Journal of Plant Reproductive Biology 10 № 1 44-51 DOI: 10.14787/ijprb.201810.1.44-51

13. Elkonin L A, Italyanskaya J V and Panin V M 2018 Genetic modification of sorghum for improved nutritional value: state of the problem and current approaches Journal of Investigative Genomics 5 № 1 39-48 DOI: 10.15406/jig.2018.05.00076

14. Elkonin L A, Kozhemyakin V V, Gerashchenkov G A, Rozhnova N A and Panin V M 2018 Epigenetic regulation of cytoplasmic male sterility in Sorghum The International Journal of Plant Reproductive Biology 10 № 2 109-118 DOI: 10.14787/ijprb.201810.2

15. Elkonin L A, Italianskaya J V, Domanina I V, Selivanov N Y, Rakitin A L and Ravin N V. 2016 Transgenic sorghum with improved digestibility of storage proteins obtained by agrobacterium-mediated transformation Russian Journal of Plant Physiology 63 678-689 DOI: 10.1134/S1021443716050046

16. Elkonin L A, Italianskaya J V, Fadeeva I Y, Bychkova V V and Kozhemyakin V V 2013 In vitro protein digestibility in grain sorghum: Effect of genotype and interaction with starch digestibility Euphytica 193 327-337 DOI: 10.1007/s10681-013-0920-4

17. Kibalnik O P, Efremova I G, Semin D S, Gorbunov V S, Kamenev O B Starchak V I and Kukoleva S S 2019Assessment of quality of grain and biomass of sorghum for use in fodder production Grain industry of Russia 4(64) 3-7 DOI: 10.31367 / 20 9-87252019-64-4-3-7

18. Starchak V I, Zhuzhukin V I, Zhuk E A and Bychkova V V 2020 Evaluation of correlation relationships of morphophysiological characteristics of grain sorghum breeding of FSBSI ROSNIISK "Rossorgo" Agricultural scientific journal № 6 38-42 DOI: 10.28983 / asj.y2 020i6pp38-42

19. Dospekhov B A 1985 Field Experiment Methodology (with the basics of statistical processing of research results) (Moscow) p 352

20. Kuperman F M 1984 Morphophysiology of Plants. Morphophysiological Analysis of 
Organogenesis Stages of Various Life Forms of Angiosperms (Moscow Higher school) p 240

21. Yakushevsky E S., Varadinov G, Korneichuk VA, Banyai L 1982 Wide Unified CMEA Classifier of Cultivated Species of Sorghum Moench Genus (Leningrad AllRussian Research Institute of Plant Industry named after N I Vavilova (VIR) p 35 